\title{
Households' Non-leisure Time Allocation for Children and Determinants of Child Labour in Punjab, Pakistan
}

\author{
ABID A. BURKI and TAZEEN FASIH
}

\section{INTRODUCTION}

Pakistan is one of those countries in Asia where incidence of child labour is very high. Children should not have to work, but the estimates of the Child Labour Survey 1996 show that there are 3.3 million working children between the ages of 5-14 years in Pakistan. Due to political, social and economic pressures, developing countries like Pakistan tend to react by enacting legislation which bans child labour. Countries which are now developed did the same thing when they successfully completed their industrialisation.

Child labour is often harmful for the children, but there are situations where the alternatives to child labour may offer only deeper poverty both for the children and their families. Therefore, mishandling of this issue can make matters from bad to worse, for example, if legislation pushes children into even worse situations. The Government of Pakistan has enacted the Employment of Children Act of 1991 which has banned employment of children below the age of 14 years and their employment is now a cognisable offence under the Act punishable by imprisonment and fine. ${ }^{1}$ Such interventions can lead to reductions in the already limited choices available to the child. For example, this legislation may mean that the child can neither work nor go to school. To put it differently, this ban does not address market failures, for example, in the education market. Hence, to tackle this complex problem different policy instruments are required which address not only the aspects of market failures, but also distributional and efficiency considerations of such services. In handling the issue of child labour, the supply side factors which motivate households to allocate non-leisure time of their children can provide useful insights to address this complex problem. Empirically, the

Abid A. Burki is Assistant Professor of Economics, Quaid-i-Azam University, Islamabad. Tazeen Fasih is an M.Phil. student in the Department of Economics, Quaid-i-Azam University, Islamabad.

${ }^{1}$ For further details on steps taken by the Government of Pakistan to eliminate child labour in Pakistan, see Hyder (1998). 
challenge is to estimate a model which captures the household's behaviour with respect to labour market participation, education, risk management and other relevant factors.

Against this background, this paper attempts to empirically investigate the supply side determinants of child labour in Punjab, Pakistan by using a reduced form model, which portrays the child labour decision as a simultaneous decision-making process. This assumption about household's decision-making toward allocation of children's time among alternative uses yields a multinomial logit model. We implement this model on a sample of 14,094 children from Punjab, Pakistan in the age cohort of 5-14 years from 4,829 households obtained from the Child Labour Survey 1996. The survey records labour force participation for all household members aged 5 years and above and contains questions on labour market participation addressed at adults and children in the household, socioeconomic conditions, employment and working conditions. Our motivation for selecting only Punjab's sample for this study is that (a) Punjab is the largest province in terms of population, hence the number of child labourers is also largest in absolute sense; (b) there is a high concentration of small-scale, informal and cottage industry in this province, where the problem of child labour is more acute. For example, the districts of Sialkot, Gunjranwala, Lahore and Faisalabad are notorious for the abuse of child labour in some major export industries, e.g. textiles and clothing, sports goods, surgical goods, etc.; and (c) due to cultural and demographic differences between the four provinces, we expect that the determinants of child labour could differ across provinces.

The plan of the paper is as follows. Section 2 lays out the general model employed for the empirical analysis. In Section 3, we describe the data and construction of variables. The empirical results of multinomial logit equations are presented and discussed in Section 4. In Section 5, the major conclusions are summarised and policy implications are discussed.

\section{THE MODEL}

Assume that households are rational decision-making units who make choices between leisure time and consumption of goods to maximise their perceived utility subject to time and budget constraints. Considering the time allocation of different members, households maximise their utility function of the form

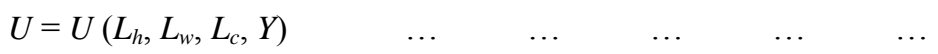

where $L_{h}$ is leisure hours for husband, $L_{w}$ is leisure hours for wife, $L_{c}$ is leisure hours for children in the household, and $Y$ represents Hicksian composite good representing consumption of all goods other than leisure. ${ }^{2}$ The households maximise their utility subject to their budget given by ${ }^{3}$

${ }^{2} Y$ is a composite Hicksian commodity under the assumption that throughout the analysis the relative prices of different commodities do not change [see for instance, Wales and Woodland (1977); Hill (1983) and Pencavel (1986).

${ }^{3}$ Here we have assumed that the leisure time does not include time spent on household activities. 


$$
W_{h} L_{h}+W_{w} L_{w}+W_{c} L_{c}+P_{y} Y=M \equiv I+W_{h} \Omega+W_{w} \Omega+W_{c} \Omega \quad \ldots \quad \ldots
$$

where $W_{h}, W_{w}$ and $W_{c}$ are wage rates of husband, wife and children, respectively, $P_{y}$ is price of composite good, $Y, I$ is non labour income, $M$ is full income and $\Omega$ is total number of hours available for work and

$$
L+\Omega=T
$$

where $T$ is the total time.

Maximising utility function subject to the constraint (2) yields the demand functions for leisure and the composite good of the husband, wife and children.

$$
\begin{aligned}
& L_{i}=F_{i}\left(W_{h}, W_{w}, W_{c}, P_{y} ; M\right) \quad i=h, w, c \\
& Y=F_{y}\left(W_{h}, W_{w}, W_{c}, P_{y} ; M\right) \quad \ldots \quad \ldots \quad \ldots \quad \ldots
\end{aligned}
$$

Substituting these optimised demand functions into the utility function yields the indirect utility function for each household. Households maximise their indirect utility functions given prices and incomes. Following McFadden (1973), we assume that due to imperfect information, knowledge and perception of the households there are errors in the maximisation process which makes household utility a random function.

Following Maddala (1983), we suppose that our households face $m$ choices for allocation of childrens' time and define a latent variable $V_{k}{ }^{*}$ denoting the level of indirect utility attached with the $k$ th choice. The variables $V_{k}$ are given by

$$
\begin{array}{lllllll}
V_{k}=1 & \text { if } V_{k}=\operatorname{Max}\left(V_{1}^{*}, V^{*}, \ldots, V_{m}^{*}\right) & & & \\
V_{k}=0 & \text { otherwise } & \ldots & \ldots & \ldots & \ldots & \ldots
\end{array}
$$

where we also assume that there are no ties. The variables $V_{k}$ are decomposed into a non-stochastic component, $V_{k}\left(X_{k}\right)$ and a stochastic component, $\varepsilon_{k}$, written as

$$
V_{k}=V_{k}\left(X_{k}\right)+\varepsilon_{k} \quad k=1,2, \ldots, m \quad \ldots \quad \ldots \quad \ldots
$$

where $X_{k}$ is the vector of attributes of the $k$ th choice and $\varepsilon_{k}$ gives the errors in perception and optimisation. More specifically, we assume that a typical household chooses among four mutually exclusive and exhaustive alternatives. These include (i) only school, (ii) school and work, (iii) only work, and (iv) no work no school. We categorise these alternatives as 1, 2, 3 and 4, respectively. A household maximises its utility function subject to the constraints imposed by each of the alternatives. The household, therefore, modifies its budget and time constraints to reflect respective costs and returns of each alternative. This results into four indirect utility functions. The child and the household compares the levels of indirect utility, which can be achieved from the various alternatives, and choose the alternative that maximises the household's indirect utility. The probability that child $i$ participates in $k$ th activity is the probability that the indirect utility from $k$ th choice is greater than that derived from other alternatives 


$$
P_{i k}=P_{r}\left(V_{i k}>V_{i j}\right) \quad \forall j \neq k, j=1,2,3,4 \quad \ldots \quad \ldots \quad \ldots
$$

This implies that the probability of individual $i$ participating in alternative $k$ is the probability that the difference between the stochastic components is greater than the difference between the non-stochastic components.

$$
P_{i k}=P_{r}\left(\varepsilon_{i k}-\varepsilon_{i j}>V_{i j}-V_{i k}\right) \quad \forall j \neq k, j=1,2,3,4 \quad \ldots \quad \ldots
$$

Assuming that the errors are independently and identically distributed with Weibull distribution then the difference between the errors has a logistic distribution [Greene (1992)] and the multinomial logit is the appropriate technique of estimation. The probabilities in the multinomial logit model are therefore given by

$$
\begin{aligned}
& \operatorname{Prob}(Y=j)=\frac{\mathrm{e}^{\beta_{j} x_{i}}}{1+\sum_{\mathrm{k}=1}^{\mathrm{J}} \mathrm{e}^{\beta_{k}{ }^{x_{i}}}} \\
& \operatorname{Prob}(Y=0)=\frac{1}{1+\sum_{\mathrm{k}=1}^{\mathrm{J}} \mathrm{e}^{\beta_{k}^{\prime} x_{i}}} \quad \text { for } j=1,2,3,4 . \quad \ldots \quad \ldots \quad \ldots
\end{aligned}
$$

where the coefficients $\beta$ 's are normalised to zero, and $x$ is the vector of explanatory variables. The multinomial logit model is identified by normalising the coefficients of one of the choices to zero. Hence we normalise the coefficients of the alternative of no work and no school to zero.

The coefficients in our model are difficult to interpret because they only provide information on the effects of the independent variables on the odds ratios. To interpret the effect of the independent variables $(x)$ on the probabilities of each choice, we calculate partial derivatives as

$$
\frac{\partial P}{\partial X}=P_{j}\left(1-P_{j}\right) \beta_{x j}-\sum_{k} P_{j} P_{k} \beta_{x k} \quad \text { where } j, k=1,2,3,4 . \quad \ldots \quad \ldots
$$

where $P$ is the probability of participation in each alternative. The log of likelihood function is derived by defining for each individual, $d_{i j}=1$ if alternative $j$ is chosen by individual $i$, and 0 if not, for the possible outcomes. Then, for each individual $i$, one and only one of the $d_{i j}$ 's is one [Greene (1992)]. The log likelihood function is given by

$$
\ln L=\sum_{i} \sum_{j} d_{i j} \ln \operatorname{Prob}\left(Y_{i}=j\right) \quad \ldots \quad \ldots \quad \ldots \quad \ldots \quad \ldots
$$


Our model is based on the assumption that the four choices available to the households about children's time allocation are independent of each other. It is also assumed that respective households consider all these choices as simultaneous open. Therefore, the supply of child labour and schooling are considered as part of a simultaneous decisionmaking process.

\section{DATA AND CONSTRUCTION OF VARIABLES}

We use micro data for the province of Punjab from the nationwide Child Labour Survey (CLS) conducted in 1996 by the Federal Bureau of Statistics, Government of Pakistan in collaboration with Ministry of Labour, Manpower and Overseas Pakistanis, and International Labour Organisation (ILO), Islamabad Office. The CLS records labour force participation for all household members aged between 5 years and above and contains questions on labour market participation addressed at adults and children in the household, socioeconomic conditions, employment and working conditions.

In the CLS, a total of 10,438 households from all the four provinces, which reported at least one child labourer, were enumerated by using cluster sampling technique on 140,298 listed households. Punjab's data comes from 5,810 households representing 55.66 percent of the total survey. We deleted 981 households from our working sample due to missing data points, and problems in matching child labourers with their mothers and mother characteristics. To illustrate, a problem with CLS is that though the relationship of each individual with the head of household is given, but the relationship with other members of the household is not given. More specifically, by design the CLS does not contain identification codes to match children with their mothers and fathers. Due to combined family system in Pakistan, households consist of more than one married couple. In consequence, it is extremely difficult to identify child's parents in households reporting more than one female in the child bearing ages. To overcome the problem of identification of the mother, we used a proxy measure to identify child's mother and excluded all households where more than one female in the age group of 24-50 years was found. This leaves us with a working sample of 14,094 children in the age cohort of 5-14 years from 4,829 households.

\section{Measuring Dependent Variables}

We assume that there are a number of different ways in which a child can allocate his/her time between different activities. For this purpose, using the information given in the CLS, we generate four categories of children as follows:

- Children who are full time students and do not work (CHILD1).

- Children who work part time and also go to school (CHILD2). 
- Children who work full time and do not go to school (CHILD3).

- Children who neither work nor go to school (CHILD4).

\section{Measuring Independent Variables}

There may be a number of economic and social factors leading households to decide whether the children should go to school, work full time, work part time and also go to school, or none of the above. The primary motivation of this study is to identify the factors which may be responsible for households' decision to select one of these options. We classify the factors that may be affecting the decision to work into child characteristics, mother characteristics, head of household characteristics, and the characteristics of the household itself. A detailed description of these characteristics is given below:

- Child characteristics include age of the child in completed years, the gender of the child, given by a dummy variable, and whether he/she has undertaken any technical or vocational training.

- Mother characteristics include the education and employment of the mother, and an interaction term of the mothers' literacy with the gender of the child. It is expected that a literate mother will not let her child work, rather she would prefer him/her to go to school.

- Head of the household characteristics include the age, sex, education and the employment of the head of the household. These variables have been included because it is expected that the head has an important role in the decision making process of the child. Again, a cross term of the literacy of head of household with the gender of the child is also included.

- Number of siblings of the child include number of children in the household in the age groups of $0-4$ years, 5-9 years and $10-14$ years.

The summary statistics of the variables used appears in Table 1. It can be seen that in category CHILD3 only 26 percent are girls. In CHILD2 category 12 percent of the children are females, which suggests that a low proportion of girls work part time. This may be so because we have not included household chores in part time work while most female children help in house keeping rather than do any other work. Another interesting point is that in all the categories, a large percentage of the mothers have no formal education. As all the households in our sample have at least one economically active child, this indicates that lack of mother education may be one of the most important factors of determining child labour. 
Table 1

\begin{tabular}{|c|c|c|c|c|c|}
\hline Variables & Description & CHILD1 & CHILD2 & CHILD3 & CHILD4 \\
\hline \multicolumn{6}{|c|}{ Child Characteristics } \\
\hline AGE & Age of child in years & $\begin{array}{c}9.108 \\
(2.366)\end{array}$ & $\begin{array}{r}11.645 \\
(1.876)\end{array}$ & $\begin{array}{r}12.161 \\
(1.845)\end{array}$ & $\begin{array}{c}8.388 \\
(2.583)\end{array}$ \\
\hline $\mathrm{AGE}^{2}$ & Age of the child squared & $\begin{array}{c}88.55 \\
(44.97)\end{array}$ & $\begin{array}{l}139.126 \\
(41.760)\end{array}$ & $\begin{array}{l}151.292 \\
(41.897)\end{array}$ & $\begin{array}{l}77.036 \\
(47.71)\end{array}$ \\
\hline FEMALE & $=1$, if the child is female & $\begin{array}{c}0.391 \\
(0.488)\end{array}$ & $\begin{array}{c}0.120 \\
(0.325)\end{array}$ & $\begin{array}{c}0.260 \\
(0.439)\end{array}$ & $\begin{array}{c}0.650 \\
(0.477)\end{array}$ \\
\hline TECH & $\begin{array}{l}=1 \text {, if the child has acquired } \\
\text { some technical / vocational } \\
\text { training }\end{array}$ & $\begin{array}{c}0.001 \\
(0.037)\end{array}$ & $\begin{array}{c}0.022 \\
(0.147)\end{array}$ & $\begin{array}{c}0.055 \\
(0.228)\end{array}$ & $\begin{array}{c}0.002 \\
(0.049)\end{array}$ \\
\hline \multicolumn{6}{|c|}{ Mothers' Education } \\
\hline ILLITERATE & $=1$, if no formal education & $\begin{array}{c}0.902 \\
(0.297)\end{array}$ & $\begin{array}{c}0.917 \\
(0.276)\end{array}$ & $\begin{array}{c}0.951 \\
(0.215)\end{array}$ & $\begin{array}{c}0.97 \\
(0.17)\end{array}$ \\
\hline PRIMARY & $=1$, if primary education & $\begin{array}{c}0.067 \\
(0.250)\end{array}$ & $\begin{array}{c}0.057 \\
(0.232)\end{array}$ & $\begin{array}{c}0.034 \\
(0.183)\end{array}$ & $\begin{array}{c}0.022 \\
(0.149)\end{array}$ \\
\hline SECONDRY & $=1$, if matric & $\begin{array}{c}0.029 \\
(0.167)\end{array}$ & $\begin{array}{c}0.022 \\
(0.147)\end{array}$ & $\begin{array}{l}0.0135 \\
(0.116)\end{array}$ & $\begin{array}{c}0.007 \\
(0.086)\end{array}$ \\
\hline HIGH & $=1$, if intermediate & $\begin{array}{c}0.002 \\
(0.045)\end{array}$ & $\begin{array}{c}0.004 \\
(0.061)\end{array}$ & $\begin{array}{l}0.0006 \\
(0.024)\end{array}$ & 0 \\
\hline LITFEM & $\begin{array}{l}\text { Mother's literacy level } X \\
\text { gender of the child where } \\
\text { female }=1\end{array}$ & $\begin{array}{c}0.047 \\
(0.213)\end{array}$ & $\begin{array}{c}0.007 \\
(0.086)\end{array}$ & $\begin{array}{c}0.007 \\
(0.085)\end{array}$ & $\begin{array}{c}0.018 \\
(0.132)\end{array}$ \\
\hline \multicolumn{6}{|c|}{ Mothers' Employment } \\
\hline EMPLOYED & $=1$, if mother employed & $\begin{array}{l}0.2811 \\
(0.449)\end{array}$ & $\begin{array}{c}0.342 \\
(0.475)\end{array}$ & $\begin{array}{c}0.334 \\
(0.472)\end{array}$ & $\begin{array}{c}0.318 \\
(0.466)\end{array}$ \\
\hline \multicolumn{6}{|c|}{ Head of Household's Characteristics } \\
\hline AGEHEAD & $\begin{array}{l}\text { Age of head of household in } \\
\text { years }\end{array}$ & $\begin{array}{l}44.318 \\
(9.053)\end{array}$ & $\begin{array}{l}44.403 \\
(9.486)\end{array}$ & $\begin{array}{l}44.495 \\
(9.852)\end{array}$ & $\begin{array}{c}44.45 \\
(9.652)\end{array}$ \\
\hline AGEHEAD $^{2}$ & $\begin{array}{l}\text { Age of the head of household } \\
\text { squared }\end{array}$ & $\begin{array}{l}2045.98 \\
(870.32)\end{array}$ & $\begin{array}{c}2061.5 \\
(960.06)\end{array}$ & $\begin{array}{l}2076.85 \\
(957.61)\end{array}$ & $\begin{array}{l}2069.17 \\
(939.29)\end{array}$ \\
\hline FHEAD & $\begin{array}{l}=1, \text { if female head of } \\
\text { household }\end{array}$ & $\begin{array}{c}0.039 \\
(0.195)\end{array}$ & $\begin{array}{c}0.043 \\
(0.203)\end{array}$ & $\begin{array}{c}0.030 \\
(0.171)\end{array}$ & $\begin{array}{c}0.045 \\
(0.208)\end{array}$ \\
\hline \multicolumn{6}{|c|}{ Education of Household Head } \\
\hline HEADLIT & $\begin{array}{l}=1 \text {, if head of household } \\
\text { literate }\end{array}$ & $\begin{array}{c}0.275 \\
(0.446)\end{array}$ & $\begin{array}{c}0.193 \\
(0.395)\end{array}$ & $\begin{array}{c}0.253 \\
(0.435)\end{array}$ & $\begin{array}{c}0.281 \\
(0.446)\end{array}$ \\
\hline HLITFEM & $\begin{array}{l}\text { Literacy of the head of } \\
\text { household X gender of the } \\
\text { child }\end{array}$ & $\begin{array}{c}0.106 \\
(0.308)\end{array}$ & $\begin{array}{c}0.018 \\
(0.135)\end{array}$ & $\begin{array}{c}0.065 \\
(0.247)\end{array}$ & $\begin{array}{c}0.184 \\
(0.388)\end{array}$ \\
\hline \multicolumn{6}{|c|}{ Employment of Household Head } \\
\hline HEMPL & $\begin{array}{l}=1, \text { if head of household } \\
\text { employed }\end{array}$ & $\begin{array}{c}0.928 \\
(0.259)\end{array}$ & $\begin{array}{c}0.905 \\
(0.294)\end{array}$ & $\begin{array}{c}0.936 \\
(0.244)\end{array}$ & $\begin{array}{c}0.926 \\
(0.263)\end{array}$ \\
\hline \multicolumn{6}{|c|}{ Age Composition of Siblings } \\
\hline $\mathrm{NCH} 0-4$ & $\begin{array}{l}\text { Number of children in the age } \\
\text { group of } 0-4 \text { years in the } \\
\text { household. }\end{array}$ & $\begin{array}{c}1.120 \\
(1.053)\end{array}$ & $\begin{array}{c}1.046 \\
(1.051)\end{array}$ & $\begin{array}{c}1.173 \\
(1.101)\end{array}$ & $\begin{array}{l}1.375 \\
(1.093)\end{array}$ \\
\hline $\mathrm{NCH} 5-9$ & $\begin{array}{l}\text { Number of children in the age } \\
\text { group of 5-9 years in the } \\
\text { household. }\end{array}$ & $\begin{array}{c}1.499 \\
(0.910)\end{array}$ & $\begin{array}{c}1.237 \\
(0.856)\end{array}$ & $\begin{array}{l}1.293 \\
(0.899)\end{array}$ & $\begin{array}{c}1.642 \\
(0.894)\end{array}$ \\
\hline NCH $10-14$ & $\begin{array}{l}\text { Number of children in the age } \\
\text { group of } 10-14 \text { years in the } \\
\text { household. }\end{array}$ & $\begin{array}{c}2.101 \\
(0.854)\end{array}$ & $\begin{array}{c}1.818 \\
(0.818)\end{array}$ & $\begin{array}{c}1.917 \\
(0.833)\end{array}$ & $\begin{array}{c}1.969 \\
(0.832)\end{array}$ \\
\hline Sample Size & & 4436 & 809 & 5090 & 3759 \\
\hline
\end{tabular}

Notes: Numbers in parentheses are standard deviations. CHILD1= Only school, CHILD2 = School and work, CHILD3 = Only work, CHILD4 $=$ No work and no school. 


\section{ESTIMATES OF MULTINOMIAL LOGIT MODEL}

The estimation results from the multinomial logit model are presented in Table 2. The estimated parameters for each category, i.e., CHILD1 - CHILD4, are obtained from a single maximum likelihood multinomial logit estimation. Table 2 reports partial derivatives at the mean of the dependent variables in bold letters followed by the logit coefficients while $t$-statistics are reported in parentheses.

Our results show that age has an important impact on the decision about work and schooling. For example, in the case of CHILD1 the estimated parameters show a concave profile. More specifically, it implies that the probability of going to school increases at a decreasing rate. Households make their decisions by weighing expected costs and benefits of each option given current information. Primary education is relatively simple and much less costly in Pakistan, if compared with middle and secondary education. Therefore, the probability of dropping out from school after primary increases. Moreover, the opportunity cost of the child's going to school increases with age since older children can earn more wages which they must forego by going to school. Consistent with this reasoning, we also find that children who combine school with work (CHILD2) remain in school for a longer period because their opportunity cost does not increase as rapidly as CHILD1. Table 2 also shows that the probability of children combining school with work increases at a decreasing rate, peaking at 13 years of age. The probability of becoming full time child workers (CHILD3) also increases with age peaking at about 16 years, which is not surprising for our data.

The results on the probabilities of female children participating in the labour force show that females are 4.7 percent less likely to attend school, 6.7 percent less likely to combine work with school, and 9.8 percent less likely to become full time workers than their male counterparts. These results depict traditional bias of parents towards sons, and social norms and traditions towards females. For instance, in Pakistan like most developing countries, boys are considered an asset for the family because of the practice that boys live with the parents and support them financially in times of need. On the other hand, girls are supposed to be liabilities as they are to be married off and given dowry at the time of their marriage. Likewise, educating daughters usually does not involve any returns to the parents. Therefore, male children are given preference in education and schooling. Social and cultural practices and traditions also serve as a major constraint due to which parents sometimes do not allow their daughters to attend school. Same is true for decisions to work at places other than the child's own home for girls. For such families/households a preferred arrangement is that mother works and girls stay home and take care of household chores.

We also find that technical training has a positive and significant effect on decisions toward both part time and full time work. Children who have undertaken some technical or vocational training are more likely to become child labourers and start work 
Table 2

Multinomial Logit Results of Child Labour in Punjab

\begin{tabular}{|c|c|c|c|c|}
\hline & Child1 & Child2 & Child3 & Child4 \\
\hline \multirow[t]{3}{*}{ Constant } & 0.174 & -0.396 & -0.853 & 1.076 \\
\hline & -4.779 & -16.168 & -11.589 & \\
\hline & $(-10.491)$ & $(-12.488)$ & $(-16.607)$ & \\
\hline \multicolumn{5}{|c|}{ Child Characteristics } \\
\hline \multirow[t]{3}{*}{ AGE } & 0.004 & 0.067 & 0.136 & -0.208 \\
\hline & 1.036 & 2.851 & 2.040 & \\
\hline & $(14.834)^{* *}$ & $(13.219)^{* *}$ & $(17.755)^{* *}$ & \\
\hline \multirow[t]{3}{*}{$\mathrm{AGE}^{2}$} & -0.003 & -0.003 & -0.003 & 0.008 \\
\hline & -0.050 & -0.108 & -0.065 & \\
\hline & $(-13.5)^{* *}$ & $(-11.048)^{* *}$ & $(-12.068)^{* *}$ & \\
\hline \multirow[t]{3}{*}{ FEMALE } & -0.047 & -0.067 & -0.098 & 0.212 \\
\hline & -1.180 & -2.744 & -1.823 & \\
\hline & $(-20.538)^{* *}$ & $(-20.442)^{* *}$ & $(-26.454)^{* *}$ & \\
\hline \multirow[t]{3}{*}{ TECH } & -0.350 & 0.025 & 0.386 & -0.061 \\
\hline & -0.744 & 1.960 & 2.697 & \\
\hline & $(-1.397)$ & $(4.506)^{* *}$ & $(7.377)^{* *}$ & \\
\hline \multicolumn{5}{|c|}{ Mothers' Education } \\
\hline \multirow[t]{3}{*}{ PRIMARY } & 0.103 & 0.022 & -0.036 & -0.090 \\
\hline & 0.751 & 0.234 & 0.290 & \\
\hline & $(4.479) * *$ & $(3.418)^{* *}$ & $(1.497)$ & \\
\hline \multirow[t]{3}{*}{ SECONDRY } & 0.137 & 0.024 & -0.044 & -0.116 \\
\hline & 0.978 & 0.952 & 0.375 & \\
\hline & $(4.088)^{* *}$ & $(2.806)^{* *}$ & $(1.313)$ & \\
\hline \multirow[t]{3}{*}{ LITFEM } & 0.184 & 0.002 & -0.135 & -0.051 \\
\hline & 0.795 & -0.094 & -0.561 & \\
\hline & $(3.866)^{* *}$ & $(-0.191)$ & $(-1.914)^{* *}$ & \\
\hline \multicolumn{5}{|c|}{ Mothers' Employment } \\
\hline \multirow[t]{3}{*}{ EMPLOYED } & -0.043 & 0.013 & 0.050 & -0.020 \\
\hline & -0.029 & 0.513 & 0.436 & \\
\hline & $(-0.556)$ & $(5.554)^{* *}$ & $(7.204)^{* *}$ & \\
\hline \multicolumn{5}{|c|}{ Head of Household's Characteristics } \\
\hline \multirow[t]{3}{*}{ AGEHEAD } & 0.006 & 0.001 & 0.003 & -0.003 \\
\hline & 0.032 & 0.019 & 0.004 & \\
\hline & $(2.493)^{* *}$ & $(0.815)$ & $(0.312)$ & \\
\hline
\end{tabular}

Table 2-(Continued) 


\begin{tabular}{|c|c|c|c|c|}
\hline \multirow[t]{2}{*}{$37: 4,908$} & \multicolumn{4}{|l|}{ Burki and Fasih } \\
\hline & Child1 & Child2 & Child3 & Child4 \\
\hline$\overline{\text { AGEHEAD }^{2}}$ & $\begin{array}{c}-0.000 \\
-0.0004 \\
(-2.682)^{* *}\end{array}$ & $\begin{array}{c}-0.000 \\
-0.0002 \\
(-1.177)\end{array}$ & $\begin{array}{c}-0.000 \\
-0.000 \\
(-0.211)\end{array}$ & 0.000 \\
\hline FHEAD & $\begin{array}{c}0.001 \\
-0.198 \\
(-1.496)\end{array}$ & $\begin{array}{c}-0.006 \\
-0.435 \\
(-1.825)^{*}\end{array}$ & $\begin{array}{c}-0.036 \\
-0.438 \\
(-2.692)^{* *}\end{array}$ & 0.041 \\
\hline $\begin{array}{l}\text { Education of Household } \\
\text { Head }\end{array}$ & & & & \\
\hline HEADLIT & $\begin{array}{c}0.007 \\
-0.037 \\
(-0.474)\end{array}$ & $\begin{array}{c}-0.018 \\
-0.436 \\
(-3.566)^{* *}\end{array}$ & $\begin{array}{c}0.001 \\
-0.108 \\
(-1.228)\end{array}$ & 0.011 \\
\hline HLITFEM & $\begin{array}{c}0.002 \\
-0.066 \\
(-0.636)\end{array}$ & $\begin{array}{c}-0.014 \\
-0.300 \\
(-0.958)\end{array}$ & $\begin{array}{c}0.007 \\
-0.027 \\
(-0.213)\end{array}$ & 0.005 \\
\hline $\begin{array}{l}\text { Employment of Head } \\
\text { of Household }\end{array}$ & & & & \\
\hline HEMPL & $\begin{array}{c}-0.001 \\
-0.021 \\
(-0.197)\end{array}$ & $\begin{array}{c}-0.024 \\
-0.441 \\
(-2.471)^{* *}\end{array}$ & $\begin{array}{c}0.023 \\
0.053 \\
(0.425)\end{array}$ & 0.002 \\
\hline $\begin{array}{l}\text { Age Composition of } \\
\text { Siblings }\end{array}$ & & & & \\
\hline $\mathrm{NCH} 0-4$ & $\begin{array}{c}-0.032 \\
-0.190 \\
(-8.447)^{* *}\end{array}$ & $\begin{array}{c}-0.004 \\
-0.133 \\
(-3.178)^{* *}\end{array}$ & $\begin{array}{c}0.017 \\
-0.003 \\
(-0.135)\end{array}$ & 0.019 \\
\hline $\mathrm{NCH} 5-9$ & $\begin{array}{c}0.001 \\
-0.023 \\
(-0.808)\end{array}$ & $\begin{array}{c}-0.005 \\
-0.126 \\
(-2.483)^{* *}\end{array}$ & $\begin{array}{c}-0.002 \\
-0.049 \\
(-1.508)\end{array}$ & 0.005 \\
\hline NCH 10-14 & $\begin{array}{c}0.065 \\
0.089 \\
(3.159)^{* *}\end{array}$ & $\begin{array}{c}-0.016 \\
-0.655 \\
(-11.999)^{* *}\end{array}$ & $\begin{array}{c}-0.070 \\
-0.574 \\
(-16.490)^{* *}\end{array}$ & 0.021 \\
\hline Actual Frequency (\%) & 31.47 & 5.74 & 36.11 & 26.67 \\
\hline Number of Observations & & 14094 & & \\
\hline Log Likelihood & & -13155.7 & & \\
\hline
\end{tabular}


at an early age. For example, children with technical training are 38 percent more likely to work full time than the reference group.

Parents' and household characteristics are critical in determining whether the child works or not. In this regard, we find that mother's education plays a positive role in child's decision to go school. For mothers with primary education, the probability of the child going to school increases by 10 percent while for children of mothers with secondary education this probability increases by around 14 percent. Similarly, the likelihood of combining school with work increases by about 2 percent for children whose mothers have primary education, and children whose mothers have obtained secondary education are 2.4 percent more likely to combine work with school. Our results show that mother's education has a negative effect on child's decision to work full time. However, this effect is statistically insignificant. These results confirm the general belief that mother's education is a key determinant of child's education as well as decision to work, i.e., educated mothers prefer to send their children to school.

Mother's literacy plays a positive role in schooling decisions for female children. For example, the interaction term of mother's literacy with gender of the child, LITFEM, shows that girls who have literate mothers are 18 percent more likely to go to school than the excluded category. The strong effect of mother's education on child's decision to go to school or work is also pronounced in parameter estimates and the probability derivatives for CHILD3, which show that the female children of literate mothers are 14 percent less likely to become child labourers. For CHILD2, however, this effect is statistically insignificant.

It is generally expected that children of working mothers are less likely to become child workers. However, our results do not confirm this hypothesis because we find that children with working mothers are 5 percent more likely to work full time and 1 percent more likely to combine school and work than children of unemployed mothers. The reason for this result may be that mother of the child might be employed due to pressing economic situation of the household, which would force more members of the household to join the labour force. Another reason is when the household owns some enterprise or farm, other members of the households are often employed in that activity. In Punjab, farming is a major occupation in rural areas, while a large number of cottage and home based enterprises are concentrated in the urban areas. These activities requires the entire household to participate in production.

The stage in life cycle of the household head is expected to have a significant effect in the case of schooling-work choice. The older the head of household, the more likely it is that the child attends school (CHILD1). Consistent with this expectation, we find a concave probability profile for the age of the household head on CHILD1. The function peaks at age 40 and declines thereafter. There is no significant effect of the age of head of household on the other two alternatives though.

In developing countries, in general, children in female headed households are 
more likely to work because of the higher dependency ratios, and also because in developing countries, work opportunities are restricted for women. ${ }^{4}$ However, in extended family systems like in Pakistan, the decision making process is more complex. This is so because other members of the household also work, and the female head may not be the only one responsible for child upbringing. This is exactly what we find from our results where female headed households are about 4 percent less likely to participate in full time work, while this effect is much weaker for CHILD2.

Literacy of the head of household is expected to positively influence household's school-work decision. But in contrast, we find that the literacy of the head of household has no statistically significant affect on CHILD1 and CHILD3 because there may be other factors strongly affecting decisions to send child to school rather than the literacy level. Nonetheless, for literate heads, children are 2 percent less likely to combine school with work. Literacy of the household head does not affect the household's decision of female children going to school or work. This is indicated by the insignificant parameters for HLITFEM in Table 2. The employment status of the head of household has no impact on the probability that the child goes to school or works. However, the head of household being employed decreases the probability of child's combining work with school by 2 percent.

To capture the affect of age composition of siblings in a household on child schooling and work, we include the siblings of the child in three age cohorts. For siblings of less than 4 years, the effect is negative on schooling and part time work decisions, which implies that the presence of children in age group of less than 4 years decreases the probability of older children's going to school or to combine school with work. For children in age cohort 5-9 years this effect is significant only for part time work where it is negative, i.e. larger number of children in this age group decrease the chances of combining work with school. Number of children in the age group of 10-14 years increases the probability of attending school only and decreases the probability of part time work and work only choices. These results are not consistent with our normal expectations. This result might be explained on the basis of the idea of "Child Specialisation" [Sidiqi and Patrinos 1995]. Child specialisation means that all the children of the household are not employed rather only one or two children are chosen to work. Reasons for child specialisation may be to supplement household income for which, often, the eldest child is chosen. Another reason is that children who are not good in studies or have chances to drop out of school are put to work so that they learn some skills. This result should, however, be interpreted cautiously because a household may consist of more than one nuclear family living together, so the number of children may not correspond to a single couple.

${ }^{4}$ For example, Boyden (1989) and Grootaert (1998). 


\section{CONCLUSIONS AND POLICY IMPLICATIONS}

This paper was an attempt to identify major supply related determinants of child labour in Pakistan. We assumed that households maximise utility by making decisions about time allocation for their children among different uses such as schooling only, part-time schooling with work, full-time schooling and no schooling and no work choices. This decision-making process among different uses of child's time is assumed to be a simultaneous process, which generates the multinomial logit model. We empirically implemented the model on 14,094 observations for the province of Punjab from the nation wide Child Labour Survey 1996.

Our results show that age and gender of the child affect a child's probability of working and going to school. Younger children are less probable to either work or be enrolled in school, the same is true for girls where a large number of girls neither work nor go to school. ${ }^{5}$ Parent characteristics play a major role in work-school decision of the child. In this regard we find that mother's education positively affects child's schooling decisions. Mother's employment, however, negatively affects the probability of child schooling and positively affects decisions to work. The literacy of the head of household, however, has no significant impact on the decision to work. The number of siblings in different age groups play a major role in children's schooling-work decisions. Children in the age group of less than four years decreases the probability of schooling, children in age group 5-9 years has no major impact on any of the choices except for negative impact on part time work. The presence of children in the age group 10-14 years, however, has a positive affect on schooling and negative effect on child work.

Our findings have several implications for policy and intervention by the government and local support groups such as non-governmental organisations (NGOs) and institutions working on self-help basis. It is imperative that easy access to schools should be made available. This would be an important step in, not only, increasing literacy rate but also decreasing child labour because a large number of children work due to non-availability of suitable institutions in certain areas. In addition there is a need to reduce the cost of schooling at middle and secondary levels. The government, may also want to expand non-formal education facilities to provide access to such working children who with age tend to become full time child labourers.

The traditional bias of parents favouring education of boys than girls need to be influenced by motivation, persuasion and intervention. For example, our finding that education of mother is a determining factor in the schooling of children implies that education of girls can go a long way in educating the future generations. This would have a positive impact on reducing child labour and improving the quality of household. Therefore, it is imperative that allocations for education should give priority to the education of girls.

${ }^{5}$ Girls are, thus, more likely to be involved household chores, but these cannot be included in the category of child labour. 
Our analysis shows that the probability of children with some skill becoming child labour is high. For such children, particularly those who are working in clusters, e.g., workshops or factories, special non-formal education programmes can be devised that also upgrade their skills.

These supply side policies can be combined with demand side policies. For example, a factor contributing in incidence of child labour in Pakistan (as in other developing countries) is lack of awareness. A comprehensive programme of awareness may be launched in collaboration with NGOs and community organisations to educate and inform people about hazards of child labour, loss of human capital and deprivation of children. These motivational measures can be combined with effective enforcement of existing laws concerning child labour in Pakistan.

\section{REFERENCES}

Boyden, J. (1989) Working Children in Lima Peru. In Williams Myers (ed) Protecting Working Children. New York: UNICEF. (Staff Working Paper No. 4.)

Greene, William H. (1992) Econometric Analysis. Second Edition. New York: Macmillan Publishing Company.

Grootaert, Christiaan (1998) Child Labour in Cote d'Ivoire: Incidence and Determinants. Report of the Social Development Department. The World Bank, Washington D.C.

Hill, M. Anne (1983) Female Labour Force Participation in Developing and Developed Countries - Consideration of the Informal Sector. Review of Economics and Statistics 63:3 459-468.

Hyder, S. Nazre (1998) Child Labour in Pakistan: Problems, Policies and Programmes. Asia-Pacific Development Journal 5:1 121-132.

Maddala, G. (1983) Limited Dependent and Qualitative Variables in Econometrics. Cambridge: Cambridge University Press.

McFadden, D. (1973) Conditional Logit Analysis of Qualitative Choice Behaviour. In Paul Zarembka (ed.) Frontiers in Econometrics. New York: Academic Press.

Pencavel, John (1986) Labour Supply of Men: A Survey. In O. Ashenfelter and R. Layard (eds) Handbook of Labour Economics. Elsevier Science Publishers.

Sidiqi, F., and H. A. Patrinos (1995) Child Labour: Issues, Causes and Interventions. The World Bank, Washington, D. C. (Human Resources Development Working Paper No. 56).

Wales, T. J., and A. D. Woodland (1977) Estimation of the Allocation of Time for Work, Leisure, and Housework. Econometrica 45:1 115-131. 